\title{
Antler Oddities in the Deer Family
}

\author{
by E. Kuyt, Hudson Bay, Sask.
}

Antler oddities in members of the deer family always give rise to a great deal of discussion. Some of these irregularities definitely appear to be related to body injuries. Calcium (carried in the blood and normally used to grow antlers) in case of a bone injury to the animal, now appears ait the site of the injury and is deposited there for bone repairs. This leaves a shortage of calcium for antler growth and may result in an unfinished rack of antlers.

Antler deformities may be due to old age, to a low level of nutrition or to hereditary factors.

Failure of a buck to grow one or more antlers (I observed this several times in Barren Ground Caribou) and permanent retention of antlers in the velvet stage are also occasionally encountered. A male sex hormone, testostertone, is responsible for the hardening of the antlers in the summer and for the shedding of the velvet in the fall. Loss of this hormone to the animal's system (e.g. by castration) will often result in a pair of permanent velvet covered antlers in the male deer.

Generally speaking, antlered female deer are of two different types: those in which antlers permanently remain in the velvet and those in which the antlers are polished and well developed, quite similar to those of the male deer. In the first type the females are usually fertile and bear young. Their antlers are often small, asymmetric and apparently never shed. In the second type examples are exceedingly rare in the White-tailed Deer. There is no evidence of these does bearing young. The antlers are more symmetrical than those in the first group and they may be shed like the ones which adorn the bucks. These does are usually hermaphrodites (having both male and female reproductive organs). One special case of this group was found to have a tumor which apparently was capable of secreting male hormones.
Two to fcur antlered does are reponted each year to the Pennsylvania Game Commission. In the past ten years an average of 33,000 antlered deer have been killed there each year; this would be about one antlered doe for each 8,000-16,000 bucks.

In Michigan, two to three antlered does are reported each year. The annual buck kill there is about 70,000 ; this makes a ratio of one antleled doe to each $23,000-35,000$ bucks. As some of the antlered does undoubtedly are not reported, the average of one antlered doe to 5,0008,000 bucks might be closer to the true average than the above figure.

Two antlered White-tailed Deer females have recently been shot in the Hudson Bay area. One was shot in October, during the emergency (early) season, the other in early November during the regular season.

I was able to gather the following information: Doe A, killed October 30,1959 , velvet antlers, both approximately 6" long and 3 " in circumference and with two points on each antler, udder lactating, but no fawns nearby. Doe B, killed November 13, 1959 , antlers in velvet, left antler 6" long, right antler about $61 / 2$ " long, both antlers about $3 \frac{1 / 4}{}$ "in circumference, one point on each antler, udder lactating, one fawn seen-possibly belonging to this doe. From this information it seems certain that both does belonged to the first type as both had velvet-covered antlers and both gave indication of being able to bear and nurse young.

Antlered does are so uncommon and our need for further knowledge about these animals is so great that hunters encountering them are urged to report the sighting or killing of any antlered doe.

\section{LITERATURE CITED}

DIEM, Kenneth L., 1958-Fertile antlered Mule Deer doe. Journal of Wildlife Management, 22 : p. 449.

DOUTT, J. Kenneth, and DONALDSON, John C., 1959-An antlered doe with possible masculinizing tumor, Journal of Mammalies of Mule Deer. Journal of Mammalogy, 40: 96-108.

ROBINETTE, W. Leslie, 1959-Anitler anomalies of Mule Deer, Journal of Mammology, 40: 96-108. 